Research Article

\title{
Site Measurement and Study of Vertical Freezing Wall Temperatures of a Large-Diameter Shield Tunnel
}

\author{
Jun Hu $\mathbb{D}^{1},{ }^{1}$ Wenbo Liu, ${ }^{2}$ Yutao Pan ${ }^{D},{ }^{3}$ and Hui Zeng ${ }^{4}$ \\ ${ }^{1}$ Associate Professor, College of Civil Engineering and Architecture, Hainan University, Haikou 570228, China \\ ${ }^{2}$ M.Sc. of Geotechnical Engineering, College of Civil Engineering and Architecture, Hainan University, Haikou 570228, China \\ ${ }^{3}$ Research Fellow, Department of Civil and Environmental Engineering, National University of Singapore, Singapore 119576 \\ ${ }^{4}$ Professor, College of Civil Engineering and Architecture, Wuyi University, Jiangmen 529020, Guangdong Province, China
}

Correspondence should be addressed to Yutao Pan; ceepany@nus.edu.sg

Received 15 February 2019; Revised 1 April 2019; Accepted 8 April 2019; Published 28 May 2019

Academic Editor: Xiong Zhang

Copyright ( 2019 Jun Hu et al. This is an open access article distributed under the Creative Commons Attribution License, which permits unrestricted use, distribution, and reproduction in any medium, provided the original work is properly cited.

\begin{abstract}
When a large-diameter shield tunnel boring machine enters or exits a tunnel, the newly exposed tunnel face is prone to instability and water seepage. In order to prevent collapse of the tunnel face, local ground improvement can be used until the permanent tunnel lining can be installed. The tunnel launching project of the Nanjing Metro Line 10 cross-river tunnel had a high stability requirement for the entry and exit phases. To this end, this project used a combination of cement treatment and ground freezing methods. In this project, field measurement of the vertical freezing improvement of the large-diameter shield tunnel was carried out. The temperature distribution and ground surface deformation of the vertical frozen soil wall at the end of the tunnel during the active freezing and maintenance freezing periods were analyzed in detail. The result shows that the surface settlement and seepage were successfully controlled by the combined cement treatment and ground freezing. On the other hand, the combination of cement treatment and ground freezing helps to control the freezing-induced heaving. The hydration heat in improved ground leads to an increase in ground temperature and this leads to additional freezing duration. It was examined that the frozen soil wall and the enclosure structure were in a good cementation condition. These measured values provide guidance on the timing of the shield departure. The project results confirmed that instability and water permeation did not occur in the tunnel face during the subsequent excavation.
\end{abstract}

\section{Introduction}

In recent years, large-diameter traffic tunnels that cross rivers or the sea have been extensively constructed in China. These tunnels are mostly located in deep permeable sand layers, soft clay layers, or a complex mixed formation of both. When launching a tunnel boring machine in permeable and weak strata, there may be problems such as piping or sudden inflow of water at the bottom of the pit and face instability [1]. In such situations, there is a need to ensure the stability of the reinforced soil at the departure and reception phases of the large-diameter tunnel entrance or exit [2].

The ground freezing method has been extensively used in tunneling as a means of controlling the settlement [3-12].
The ground freezing approaches were found to be effective in controlling the settlement and seepage during ground freezing. However, significant heaving and subsequent thawing also contribute to the ground disturbance.

$\mathrm{Hu}$ and Yang [13] studied the development behavior of large-diameter cup-shaped frozen wall temperature fields and the influence of different soil layers on the temperature field using numerical simulation. Similar numerical approaches are available in $[12,14]$. Hu et al. [15] introduced artificial freezing rescue technology for shallow-buried tunnels that cross thin water-rich strata. Vertical freezing and waterproof construction technology were used in the tunnel when it passed through a thin water-rich layer, and the water tightness of the tunneling construction was successfully maintained. The construction schemes of tunnels 
passing through thin water-rich layers were compared. Finite element analysis was used to check the strength of the freezing project, and temperature measurement data were obtained for the freezing construction condition. $\mathrm{Hu}$ et al. [15] reported that this approach can be used a rescue option when constructing shallow-buried underground tunnels due to the flexibility of arranging freezing pipes and prompt effect. The layout of the freezing pipes depends significantly on the specific location and type of incident (e.g., local collapse induced by piping and sudden inflow of water without collapse), which may be totally random and requires flexible and prompt rescue measures. This is very different from the situation at the departure and reception of crossriver tunnels in this study. In addition, the construction conditions at the site described in the present report were complex, comprising a high water pressure sand stratum with strong water permeability. The location also was complexed by the near-river location where the groundwater recharge was rapid. All of these factors make vertical freezing construction difficult to implement.

The contributions of the present report are as follows: (1) Field-measured data are provided for the vertical freezing temperature field at the end of the large-diameter cross-river tunnel. To date, very little on-site measured data have been reported for large-diameter vertical freezing installations. (2) The end freezing method introduced in this paper employs a freezing method after the cement/soil is strengthened with cement. The present report is the first to reveal how much the temperature of the soil increased after the soil was strengthened with cement. This report also is the first to reveal the magnitude of the freeze expansion displacement when vertical freezing is applied after the soil was strengthened with cement. (3) The freezing temperature of the cement/soil mix was confirmed from the on-site measured data.

\section{Project Overview}

The total length of the Nanjing subway route-10 is $41.4 \mathrm{~km}$, with 20 stations. This route was the first cross-river tunnel subway in Nanjing, which was scheduled to go into service in early 2015. The cross-river tunnel (double-lane single tunnel) was constructed by large-diameter shield tunneling. The start point was located at the intermediate airshaft to the north of the Yangzi River. The tunnel crosses Yangzi River in an eastward direction to the northern bank levee of the Chengnan River, Xianzhou, the main channel of Yangzi River, Meizizhou levee of the Yangzi River, and Jiangxinzhou station, as shown in Figure 1(a). The strata distribution of the launch shaft is shown in Figure 1(b).

The large-diameter shield of the Nanjing Metro Line 10 cross-river tunnel had a length of $21 \mathrm{~m}$, a width of $19.4 \mathrm{~m}$, and a buried depth of about $30.5 \mathrm{~m}$. The enclosure structure was in the form of a diaphragm wall. The main length of the shield machine was $14.5 \mathrm{~m}$, the diameter of the excavation was $12.0 \mathrm{~m}$, and the depth of the center of the shield launching tunnel was $21.0 \mathrm{~m}$. Groundwater in the construction area was mainly phreatic water and confined water. The groundwater level was about $1.4 \mathrm{~m}$ below the ground surface, and the height of the micropressure water head was $2.0 \sim 4.0 \mathrm{~m}$.

The main physical and mechanical parameters of the soil stratum involved in the initiation of the shield are shown in Table 1. It can be seen from Figure 1(b) and Table 1 that the upper part of the stratum was a weak clayey soil, and the lower part was a strong water-permeable sand layer, which frequently involved mixed-face tunneling at the two soil interfaces. Previous studies [16-18] indicated that mixedface tunneling is prone to tunnel face instability and seepage accidents. In order to ensure the smooth launching of the shield tunneling procedure, local ground improvement is usually carried out at the entrance and exit of such tunnels. Common methods are cement treatment, e.g., [1] and use of the freezing method. The former leads to the formation of a continuous wall with high strength and low permeability through cement hydration and a pozzolanic reaction within a certain curing time [19]. However, deep-mixed or jetgrouted mixing piles usually have random untreated areas due to inevitable error though they were installed with due discretion [20-26]. These untreated areas have an adverse effect on the strength and water-tightness of the treated ground [24, 25, 27-29]. In the latter case, the temperature of the surrounding soil is lowered to freezing point by a supply of low-temperature-concentrated saline solution into the freezing pipe, so that the pore water of the soil is frozen, thereby temporarily improving the strength and watertightness of the soil. However, this method will bring about large frost heave, leading to thaw collapse deformation, which will cause the freezing method to result in greater disturbance to the surrounding soil during use and decommissioning. In order to improve the strength and water-tightness of the soil and prevent large frost heaving and thaw collapses, the present project used a combination of cement-soil improvement and the freezing method.

Cement-soil improvement for this project used tripleshaft deep-mixed piles. Each cement-mix pile had a diameter of $1000 \mathrm{~mm}$, and the center distance of the pile was $750 \mathrm{~mm}$, this giving an overlap of $250 \mathrm{~mm}$. The triple-shaft mixing piles were used as the main improvement method for the end of the shield well. The improvement range was $5 \mathrm{~m}$ on both sides of the shield tunnel and the ground was strengthened from the surface to a depth of $6 \mathrm{~m}$ below the arch bottom. Longitudinal improvement was done for $17 \mathrm{~m}$ along the direction of the shield excavation, and the depth of the improvement zone was about $33.7 \mathrm{~m}$. In order to improve the strength of the reinforced cement/soil and the intermediate wind well enclosure structure, two rows of vertical freezing pipes were arranged along the excavation direction on the outer side of the shield initial well enclosure structure (row spacing $800 \mathrm{~mm}$, spacing $800 \mathrm{~mm}$ ). The actual improvement method and scope are shown in Figure 2.

The construction parameters of the cement/soil mixing pile are as follows:

According to the design requirements, the strength of the soil in the weak improvement zone should not be lower than that of the undisturbed soil, and the strength of the strong improvement zone shall not be less than 1.0 MPa. P.o. 42.5 ordinary Portland cement was used in the soil/cement 


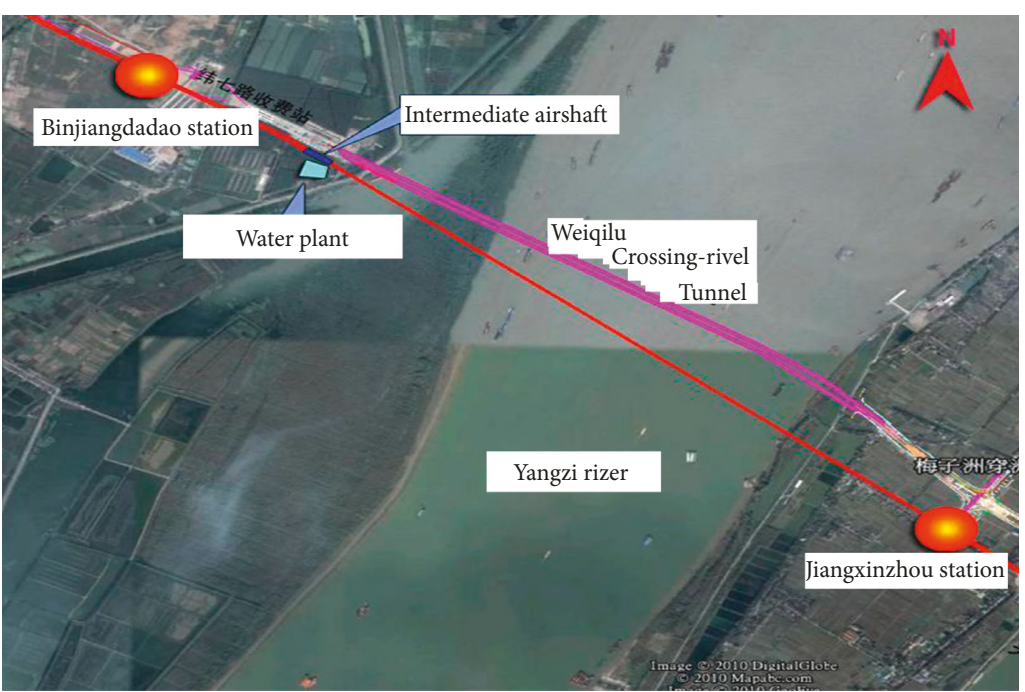

(a)

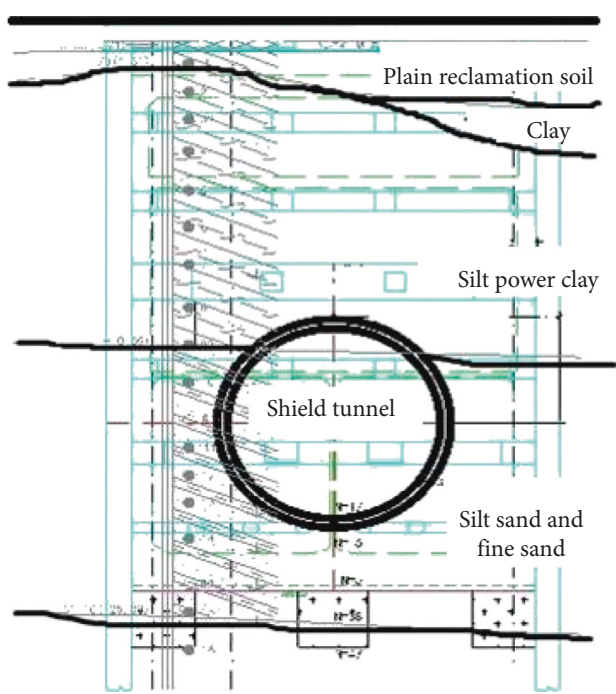

(b)

FIgURE 1: River tunnel of Nanjing subway Route-10: (a) plan view; (b) strata distribution of east shield launching well.

TABle 1: Physical-mechanical parameters of soil horizons at shield launching spot.

\begin{tabular}{|c|c|c|c|c|c|c|c|c|c|}
\hline Soil name & $\begin{array}{l}\text { Unit weight } \\
\gamma\left(\mathrm{kN} / \mathrm{m}^{3}\right)\end{array}$ & $\begin{array}{l}\text { In-situ water } \\
\text { content }(\%)\end{array}$ & $\begin{array}{c}\text { Liquid } \\
\text { limit (\%) }\end{array}$ & $\begin{array}{c}\text { Plastic } \\
\text { limit (\%) }\end{array}$ & $\begin{array}{l}\text { Poisson's } \\
\text { ratio }\end{array}$ & $\begin{array}{c}\text { Elastic } \\
\text { modulus } \\
(\mathrm{MPa})\end{array}$ & $\begin{array}{l}\text { Cohesion } \\
\quad(\mathrm{kPa})\end{array}$ & $\begin{array}{l}\text { Angle of } \\
\text { friction } \\
\text { (degree) }\end{array}$ & $\begin{array}{c}\text { Coefficient of } \\
\text { permeability } \\
(\mathrm{m} / \mathrm{s})\end{array}$ \\
\hline $\begin{array}{l}\text { (1)- } 2 \text { element fill } \\
\text { stratum }\end{array}$ & 16.5 & 52.3 & 43.5 & 24.6 & 0.36 & 7.0 & 26.0 & 7.9 & $5 \times 10^{-9}$ \\
\hline $\begin{array}{l}\text { (2)-1a2-3 clay } \\
\text { layer }\end{array}$ & 18.1 & 40.6 & 44.1 & 22.9 & 0.30 & 7.9 & 18.0 & 13.2 & $5 \times 10^{-10}$ \\
\hline $\begin{array}{l}\text { (2)- } 2 \text { b4 muddy- } \\
\text { silty clay layer }\end{array}$ & 16.7 & 30.3 & 35.3 & 20.4 & 0.32 & 6.2 & 18.0 & 15.3 & $5 \times 10^{-9}$ \\
\hline $\begin{array}{l}\text { (2)-3d3-4 silt } \\
\text { sand layer }\end{array}$ & 18.8 & 16.8 & - & - & 0.26 & 20.0 & 8.0 & 31.5 & $9 \times 10^{-6}$ \\
\hline $\begin{array}{l}\text { (2) }-5 \mathrm{~d} 1 \text { silt sand } \\
\text { layer }\end{array}$ & 19.4 & 22.1 & - & - & 0.26 & 24.2 & 6.0 & 27.3 & $2 \times 10^{-5}$ \\
\hline
\end{tabular}

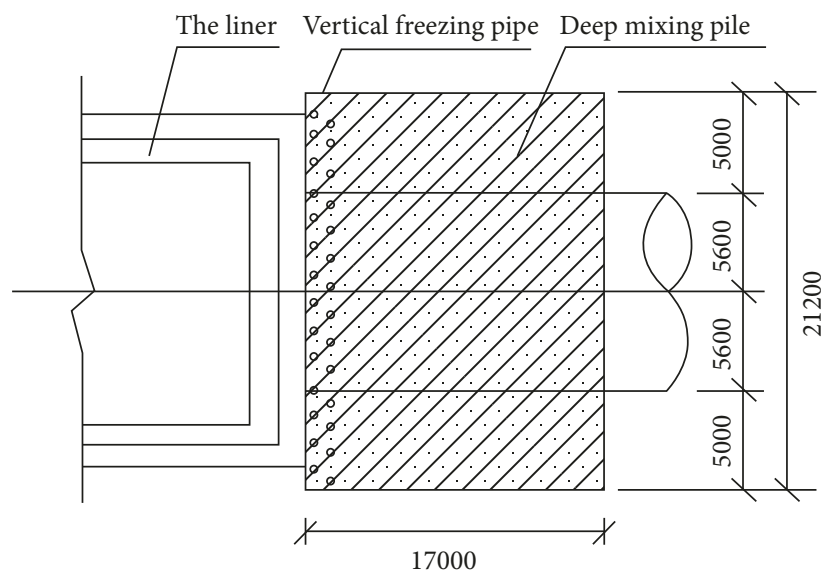

(a)

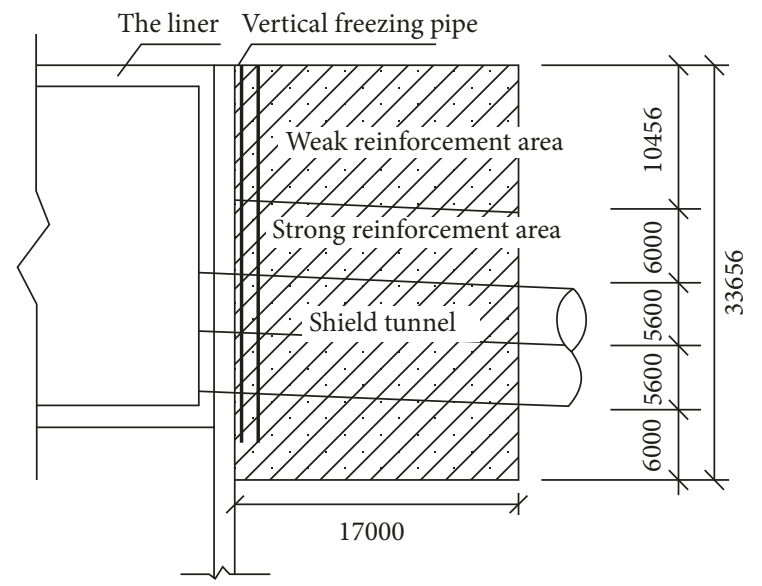

(b)

FIgURe 2: Practical improvement method and area (unit: mm). (a) Plane view; (b) cross section. 
mixture. Details of the cement deep mixing are summarized in Table 2. After 28 days of curing, drill two holes were made at any position in the improvement area of the tunnel opening to sample the pile foundation. Each hole was sampled in three locations, from the upper, middle, and lower sections, for inspection. The best mix ratio was selected on the basis of indoor cement-soil mixture ratio tests. The technical parameters of the triple-shaft cement/soil mix pile construction are shown in Table 3.

The vertical freezing arrangement used two rows of freezing holes, which were arranged in an equilateral triangle shape. 'Row A' was $0.4 \mathrm{~m}$ away from the diaphragm wall, while 'Row B' was $0.8 \mathrm{~m}$ away from Row $\mathrm{A}$. The hole spacing was $0.8 \mathrm{~m}$. There were 29 and 28 freezing holes in Rows A and $B$, respectively, which resulted in a total of 57 freezing holes (Figure 2). The depth of each freezing hole was $31.2 \mathrm{~m}$, and the total drilling depth was $1775.7 \mathrm{~m}$. The freezing pipe utilized $\Phi 127 \times 4.5 \mathrm{~mm}$ seamless steel pipe, and the feeding pipe was $\Phi 48 \times 3.5 \mathrm{~mm}$ seamless steel pipe. The saline temperature during the active freezing period was $28^{\circ} \mathrm{C} \sim-30^{\circ} \mathrm{C}$, and the saline temperature during the maintenance freezing period was $-25^{\circ} \mathrm{C} \sim-28^{\circ} \mathrm{C}$. The active freezing period was 30 days. The design parameters of the vertical freeze are shown in Table 2.

\section{Overview of Field Measurements}

Using the field-measured data from February 15, 2012 to April 15, 2012, the temperature and surface deformation of the vertical frozen soil wall in the active freezing and maintenance freezing periods were analyzed in detail to determine whether the vertical frozen soil wall had reached design requirements so that the timing of the door chiseling and shield launching could be determined.

3.1. Purpose of the Field Measurements. The purpose of field measurement was as follows:

(1) To study the original ground temperature of cement/ soil mixture before and after improvement.

(2) Via field measurements of the loop temperature of the saline solution in each freezing pipe, determine if the pipe has been blocked. The temperature of the saline solution in the main pipe was monitored to ensure it reached the requisite design temperature.

(3) To evaluate the variation behavior of the temperature distribution of the frozen soil wall during the development of the vertical freezing condition and monitor the speed of development of frozen soil and the average temperature of frozen soil wall. The field measured data then were used to determine whether the vertical frozen soil wall met the design requirements in order to judge the timing of shield launching.

(4) To measure the interface temperature between the vertical frozen soil wall and the enclosure structure, then judge the degree of cementation of the frozen soil and the enclosure structure, in order to determine the timing of door chiseling.

(5) To study the displacement variation behavior of the surface soil in the vertical freezing area after cement/ soil improvement.

3.2. Instrumentation. The measured data were collected from the start of the freeze on February 15, 2012 at 18:00, and the program lasted for 60 days until April 15, 2012.

The location of each monitoring point is shown in Figure 2. There were two rows of freezing holes in the vertical freezing area, and the saline solution was supplied by the main pipe of the saline loop. The 57 freezing holes were divided into 19 branches. Monitoring points were installed on the loop feeding pipes of the main pipe, and the 19 branches to measure the saline loop temperatures of the freezing holes were maintained within specification.

There were 6 temperature measurement holes in the vertical freezing zone, and each temperature measuring hole had 10 temperature measurement points, which were located at $5 \mathrm{~m}, 10 \mathrm{~m}, 15 \mathrm{~m}, 17 \mathrm{~m}, 19 \mathrm{~m}, 21 \mathrm{~m}, 23 \mathrm{~m}, 25 \mathrm{~m}, 27 \mathrm{~m}$, and $31 \mathrm{~m}$ below the ground surface. The serial number is $\mathrm{C} i-j$ in order ( $i$ indicates the temperature measurement hole number, $j$ indicates the measurement point number, and the number increases with the increase of the buried depth).

Two surface soil displacement monitoring sections DB1 and DB2 were arranged along the tunnel excavation direction in the freezing area. The DB1 section was located between the A row of freezing holes and the enclosure structure, and the DB2 section was located between the A row and the $\mathrm{B}$ row of freezing holes. 13 monitoring points were arranged in each section and were arranged symmetrically with the axis of the tunnel as the axis of symmetry, with a spacing of $1.9 \mathrm{~m}$.

\section{Results and Analysis of the Field Measurements}

4.1. Analysis of Original Ground Temperature in the Vertical Freezing Area. The end soil in this project was strengthened by cement before vertical freezing and the original ground temperature increased due to the influence of the hydration heat of the cement. The initial temperature at each measured point in the temperature measurement hole was taken as the approximate value of the original ground temperature to study the change in the ground temperature of the cement/ soil before and after improvement. The C1, C3, and C5 locations were at the edge of the cement modified improvement and were close to the enclosure structure; therefore, they were subjected to heat exchange and heat convection from the enclosure structure and the outside air. In addition, the initial temperature of each point at $\mathrm{C} 1, \mathrm{C} 3$, and C5 was monitored after a few days of saline solution circulation. Therefore, the data from these three temperature measurement holes were not evaluated.

After 28 days of curing in the cement/soil reinforced zone, the temperatures of the $\mathrm{C} 2, \mathrm{C} 4$, and $\mathrm{C} 6$ measuring points are shown in Figure 3. It can be observed from the 
TABLE 2: Design parameters of verticle ground freezing.

\begin{tabular}{|c|c|c|c|}
\hline Name & Parameter value & Name & Parameter value \\
\hline Freezing pipe & $\begin{array}{c}\varphi 127 \times 5 \mathrm{~mm} 20 \# \text { low-carbon steel } \\
\text { seamless steel pipe }\end{array}$ & Saline temperature & $-28 \sim-30^{\circ} \mathrm{C}$ \\
\hline Feeding pipe & $\varphi 48 \mathrm{~mm} \times 3.5 \mathrm{~mm}$ seamless steel pipe & Vaporization point & $-33 \sim-35^{\circ} \mathrm{C}$ \\
\hline Temperature measurement pipe & $\varphi 45 \times 3 \mathrm{~mm}$ seamless steel pipe & $\begin{array}{l}\text { Freezing zone original stratum } \\
\text { temperature* }\end{array}$ & $\leq+30^{\circ} \mathrm{C}$ \\
\hline Hole number & $\begin{array}{l}57 \text { vertical freezing holes and } 6 \\
\text { temperature measuring holes }\end{array}$ & Cooling water temperature & $+23^{\circ} \mathrm{C}$ \\
\hline Depth of freezing hole & $31.2 \mathrm{~m}$ & Condensation temperature & $+35^{\circ} \mathrm{C}$ \\
\hline Total length of freezing hole & $1775.7 \mathrm{~m}$ & Cooling loss coefficient & 1.2 \\
\hline $\begin{array}{l}\text { Total length of temperature } \\
\text { measuring hole }\end{array}$ & $93.5 \mathrm{~m}$ & Total required cooling & $\begin{array}{c}Q=22.7 \text { ( } 10,000 \text { calories } \\
\text { per hour })\end{array}$ \\
\hline
\end{tabular}

*The original stratum temperature refers to the temperature after curing for 28 days.

TABLE 3: Construction parameters for triple-shaft mixing pile.

\begin{tabular}{lccc}
\hline Name & Technical parameter & Name & Technical parameter \\
\hline Rate of sinking $(\mathrm{m} / \mathrm{min})$ & $0.4 \sim 1.0$ & Cement grading & P.O $42.5 \mathrm{R}$ \\
Uplift velocity $(\mathrm{m} / \mathrm{min})$ & $0.4 \sim 1.0$ & Cement content & Strongly reinforced region $20 \%$, weekly reinforced \\
Grouting pressure $(\mathrm{MPa})$ & $1 \sim 2$ & Grout coordinate ratio & Water: Cement $=1.5: 1$ \\
\hline
\end{tabular}

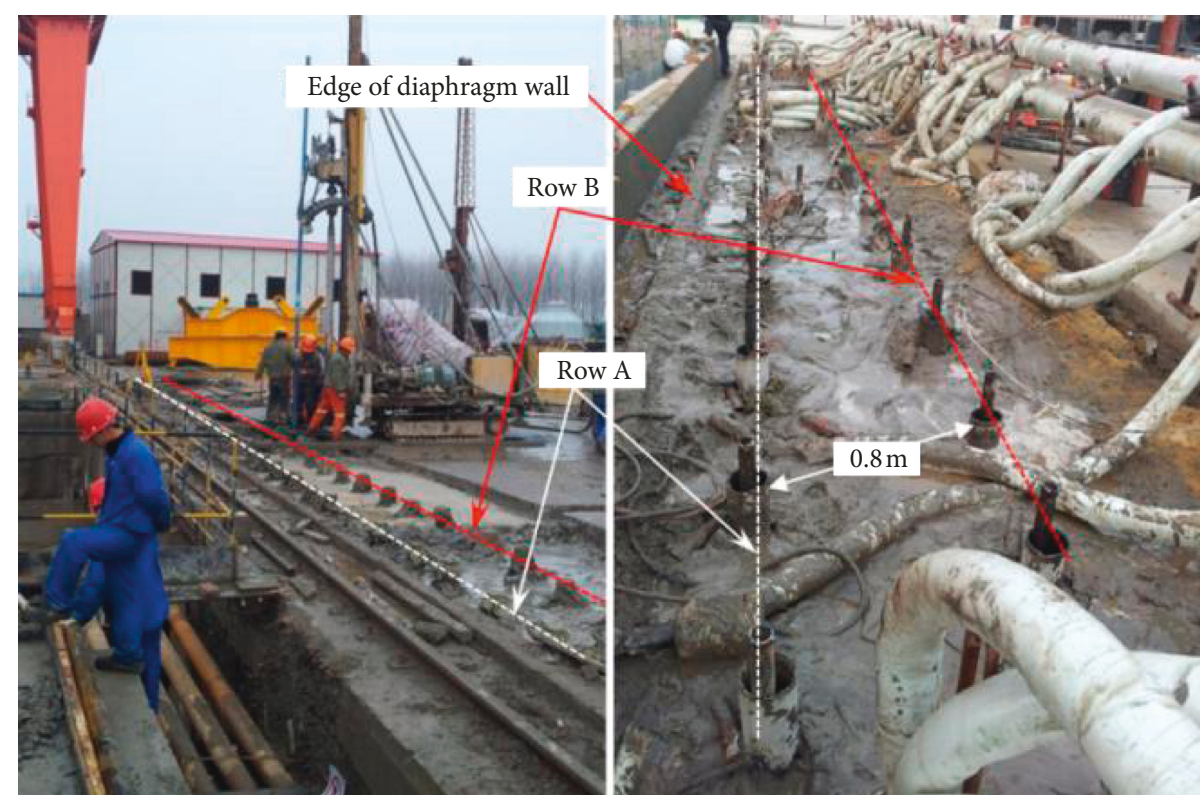

FIgURE 3: Layout of vertical freezing pipes.

figure that the initial temperature in the tunnel depth range was concentrated at $32^{\circ} \mathrm{C}$ to $39^{\circ} \mathrm{C}$. It was then estimated that the ground temperature after cement improvement should be between $35^{\circ} \mathrm{C}$ and $40^{\circ} \mathrm{C}$. The temperature at the bottom of the C2, C4, and C6 temperature measurement holes decreased. There may have been two reasons for this: (1) This location was at the bottom boundary of the cement/soil reinforced zone, and its temperature was easily reduced by the conductivity of the low-temperature soil in the surrounding untreated zone. (2) Due to the axial offset $[22,23,28]$, the improvement effect of the triple-shaft cement mix pile was not good, and it was difficult to form a uniform cement/soil improvement zone [21]. Therefore, the cement hydration heat was less than the upper part. Before the cement strengthening stage, it was known from the preconstruction investigation report that, below $10 \mathrm{~m}$, the end stratum was basically a constant temperature zone, which is not affected by solar radiation. The average ground temperature in the tunnel depth range of the same month in last year was between $17^{\circ} \mathrm{C}$ and $18^{\circ} \mathrm{C}$. Therefore, it was known that the hydration heat of the cement/soil mixture caused the stratum temperature to rise by about $17^{\circ} \mathrm{C}$ to $23^{\circ} \mathrm{C}$ after 28 days of curing. 
4.2. Analysis of Saline Loop Temperature Measurements. The period from the start of freezing to the end of active freezing was 30 days, followed by the maintenance freezing period. The saline loop temperature variation curve for the main pipe is shown in Figure 4. During the initial stage of active freezing, the temperature fell from the fourth day to the seventh day after the start of freezing. After that, the saline temperature rose rapidly. The construction unit found there was a quality fault in the refrigerating machine unit used. In order to ensure the safety of the entire vertical freezing process, the old equipment was replaced with a new set of freezing equipment. After the equipment was replaced, the temperature of the forward main pipe was reduced to $-21^{\circ} \mathrm{C}$ when frozen for 10 days, and the temperature dropped to $-30^{\circ} \mathrm{C}$ when frozen for 19 days. The temperature of the main pipe was maintained at $-31^{\circ} \mathrm{C}$ during maintenance freezing. During the active freezing period (0-30 days), the average temperature difference of the main pipe was $1.9^{\circ} \mathrm{C}$, and the average temperature difference during the maintenance freezing period (30-60 days) was $0.8^{\circ} \mathrm{C}$. These results show that the amount of heat exchange was large at the beginning of freezing, and then gradually decreased. After entering the maintenance freezing stage, the heat exchange became stable.

In order to find out whether any sections of the freezing pipe contained airlocks or blockage, the temperatures of the saline solution in the 19 branches were monitored. The results are shown in Figure 5. As the saline solution in the 19 forward branches all come from the forward main pipe and the saline solution in the 19 return branches are all collected in the return main pipe, the variation curves of the 19 loop branches are basically the same as those of the main loop. Thus, it was confirmed no air locks or blockages were present in any of the freezing pipes.

4.3. Analysis of the Development of the Frozen Vertical Soil Wall. Before the shield is launched, the thickness of the frozen soil wall must reach the design requirement of $2 \mathrm{~m}$, the average temperature should be lower than $-10^{\circ} \mathrm{C}$, the saline loop temperature difference of the main pipe should be less than $2^{\circ} \mathrm{C}$, and the interface temperature between the frozen soil and the trench wall in the drill hole of the tunnel cave door should be less than $-5^{\circ} \mathrm{C}$. Only then can the tunnel door can be removed. Figures 6-13 show the temperature monitoring data for the measuring points in the temperature measurement holes during the whole measurement period.

Because the C2 temperature measurement hole has poor hole-quality during drilling and may have serious deflections, these affect the installation of the thermocouple. Therefore, the data of this group were quite different to the data of other temperature measurement holes. As a result, Figure 7 is presented only for reference during analysis. The measurement points of the C6 temperature measurement holes at $23 \mathrm{~m}, 25 \mathrm{~m}$, and $31 \mathrm{~m}$ were damaged by construction, so there are no data.

It can be observed from the figure (the C4 and C5 temperature measurement holes are similar) that because the front end soil was reinforced with the triple-shaft deep soil/concrete mix piles before vertical freezing, the original ground temperature was high and was $35^{\circ} \mathrm{C} \sim 40^{\circ} \mathrm{C}$. When freezing had been in progress for 7 days, the soil temperature decreased from the original ground temperature to below $5^{\circ} \mathrm{C}$. At this stage, the saline solution temperature, as provided by the refrigeration machine, fell rapidly to $-12^{\circ} \mathrm{C}$. The temperature difference between the soil and the cold solution in the freezing pipe was large, so the rate of heat exchange was high. The temperature of the soil decreased rapidly because the temperature of the saline solution was still falling. After that, due to the replacement of the refrigerating machine unit, the rate of temperature decrease of the soil slowed down. After freezing for 8 days, the temperature slowly fell into the phase transition stage. The phase transition stage lasted for about 4 days, and it ended after 16 days of freezing. From the 16 th day of freezing until the end of the active freezing period, the temperature of the soil begins to decrease rapidly again from $-2^{\circ} \mathrm{C}$. At this stage, the temperature of the saline solution in the freezing pipe was $-28^{\circ} \mathrm{C} \sim-30^{\circ} \mathrm{C}$. After entering the maintenance freeze condition, the temperature of the saline solution in the freezing pipe was between $-30^{\circ} \mathrm{C}$ and $-32^{\circ} \mathrm{C}$, and the temperature difference of the saline solution in the main loop pipe gradually decreased from $2^{\circ} \mathrm{C}$ to about $1^{\circ} \mathrm{C}$. The soil temperature was maintained at a near-static value. The temperature measurement points of $\mathrm{C} 1$ were maintained at around $-25^{\circ} \mathrm{C}$, except for the bottom of the frozen pipe at a depth of $31 \mathrm{~m}$. The bottom of the freezing pipe had more unfrozen soil around it, so the cooling process was clearly different from that of the other points, and the temperature was higher than that at other points. The temperatures of points $\mathrm{C} 1$ and $\mathrm{C} 3$ between the Row A pipe and the enclosure structure were almost always maintained at $-25^{\circ} \mathrm{C}$, indicating that the temperature between the vertical frozen wall and the enclosure structure was around $-25^{\circ} \mathrm{C}$. Most of the $\mathrm{C} 5$ points between the Row A and Row B pipes were maintained between $-25^{\circ} \mathrm{C}$ and $-30^{\circ} \mathrm{C}$, which was lower than the temperatures of the $\mathrm{C} 1$ and $\mathrm{C} 3$ points, indicating that the temperature between the two rows of freezing pipes was between $-25^{\circ} \mathrm{C}$ and $-30^{\circ} \mathrm{C}$. The temperature of each point of $\mathrm{C} 4$ and $\mathrm{C} 6$ that were $0.3 \mathrm{~m}$ outside the Row $\mathrm{B}$ pipe was maintained at $-20^{\circ} \mathrm{C}$ and $-25^{\circ} \mathrm{C}$.

According to the indoor test, the freezing temperature of the soil after cement improvement at the project site was in the range of $-0.4^{\circ} \mathrm{C}$ to $-2^{\circ} \mathrm{C}$. From the above figures, a clear temperature inflection point can be observed. The temperature at the inflection point is the freezing temperature of the improvement. The temperature range was $-0.4^{\circ} \mathrm{C} \sim-2^{\circ} \mathrm{C}$, indicating that the results of the laboratory test reflected well the site condition.

The points of the C5 temperature measurement hole indicated that the phase change stage was being entered when freezing had been in progress for 12 days, confirming the closure of two rows of frozen soil at this time. The phase transition completion time for each point in the C4 and C6 temperature measurement holes was about 26 days and 24 days, while the points of $\mathrm{C} 1, \mathrm{C} 3$, and C5 temperature measurement holes completed the phase transition stage in about 16 days, indicating that the integral vertical frozen wall has been formed at this time. 


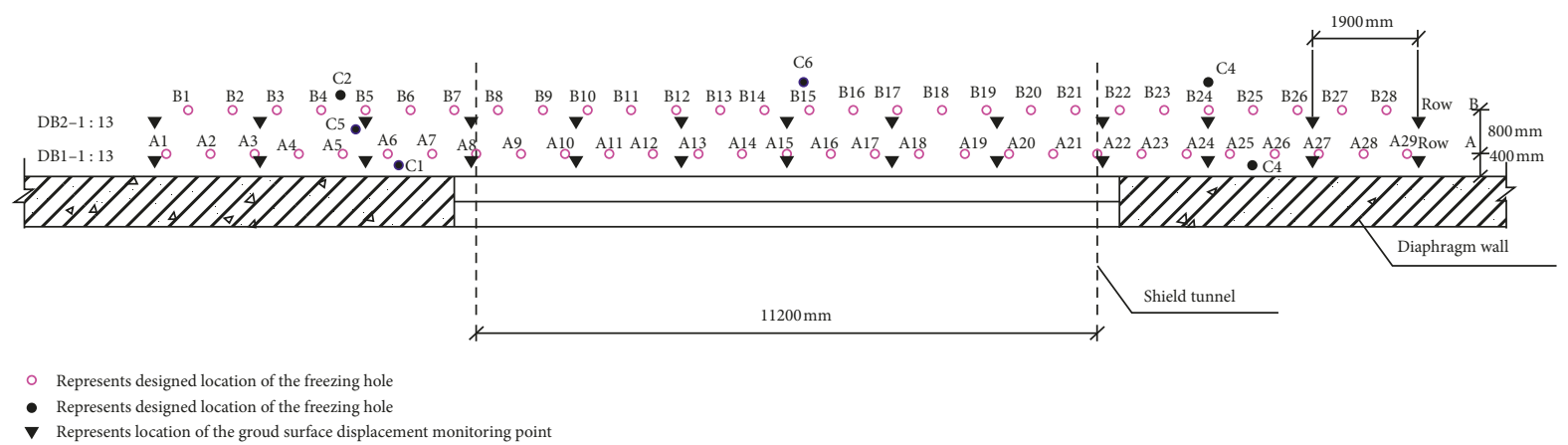

FIgURE 4: Layout of monitoring locations.

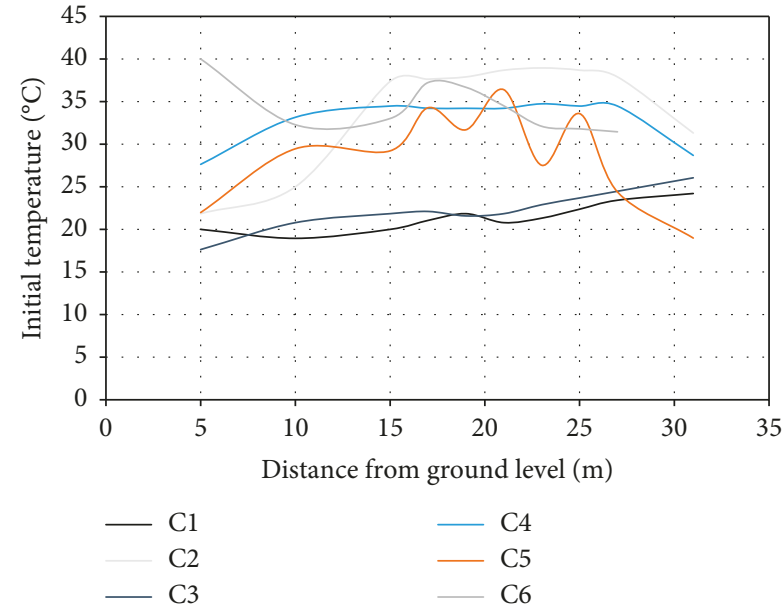

Figure 5: Distribution of the original temperature of C2, C4, and C6.

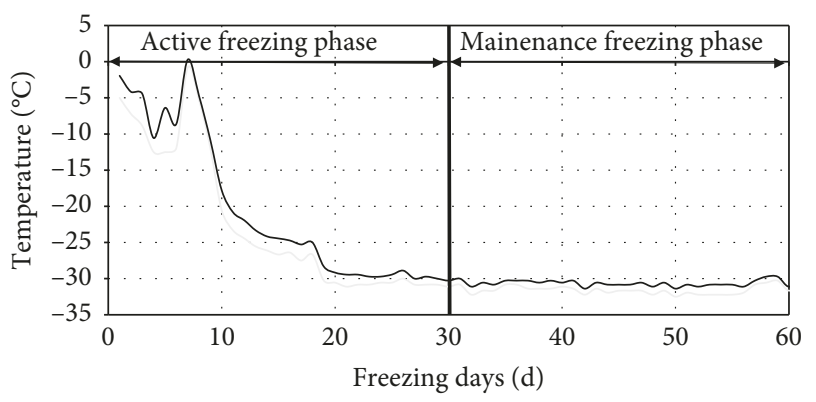

Forward circuit of the main pipe

— Return circuit of the main pipe

Figure 6: Temperature variation curves of saline solution in the main pipe loop.

4.4. Measurement and Analysis of Interface Temperature between the Vertical Frozen Soil Wall and the Enclosure Structure. In order to study the cementation of the vertical frozen soil wall and the enclosure structure, so that the timing of the tunnel door chiseling could be set, the interface temperature between vertical frozen soil wall and enclosure structure was measured. After freezing for 15 days, the trench wall was cut off. When the thickness was halfway through the trench wall, a number of holes were regularly drilled on the tunnel door to judge the integrity of the frozen wall and the trench wall cementation. The arrangement of the probe holes and the measured temperature of each probe hole are shown in Figure 14. The probe holes entered the diaphragm wall $10 \sim 15 \mathrm{~cm}$. A thermometer was used for the measurements, and it was required that the measured temperature of each probe must be below $-5^{\circ} \mathrm{C}$. The hole measurement was continued from March 30th to April 4th. It can be seen that the temperature of the probe hole was mostly maintained at $-7^{\circ} \mathrm{C} \sim-15^{\circ} \mathrm{C}$. The temperature of the probe hole 7 was the highest and was maintained at $-7^{\circ} \mathrm{C}$. The temperature of probe hole 6 was the lowest and was maintained at $-23^{\circ} \mathrm{C}$. The temperature of the probe hole 6 was lower than necessary because the Row A freezing pipe at the corresponding position was skewed and biased toward the probe hole 6 so that temperature was the lowest. The temperature of all the holes in the measured period was lower than $-5^{\circ} \mathrm{C}$. It was judged that the frozen soil wall and the enclosure structure were in good condition. Therefore, the tunnel door was removed as of April 5th.

4.5. Measurement and Analysis of Ground Displacement in the Vertical Freezing Area. The construction factors affecting the displacement of the end ground surface mainly included freezing hole construction, frozen soil frost heave, tunnel door removal, and shield launching and excavation. During the process of active freezing, as the water in the soil freezes, its volume expands and thus will cause frost heave, which results in uplift deformation on the ground surface of the freezing zone. After the end of the freezing, as the ice in the soil melts, the strength of the soil decreases and thaw subsidence of the soil occurs. The variation in ground surface displacement of the vertical freezing zone is shown in Figures 15 and 16. It can be seen from these figures that during the active freezing stage, the temperature drops. Its volume expansion causes freeze expansion of the surface ground. Figures 15 and 16 show that the magnitudes of the freeze expansion of the DB1 and DB2 sections reached their near-maximum values after a freezing time of 16 days and were $4 \mathrm{~mm}$ and $7 \mathrm{~mm}$, respectively. At this time, the C1, C3, and C5 temperature measuring holes completed the phase change at each point to form a completely frozen vertical soil wall. That is, when the whole vertical frozen soil wall was 

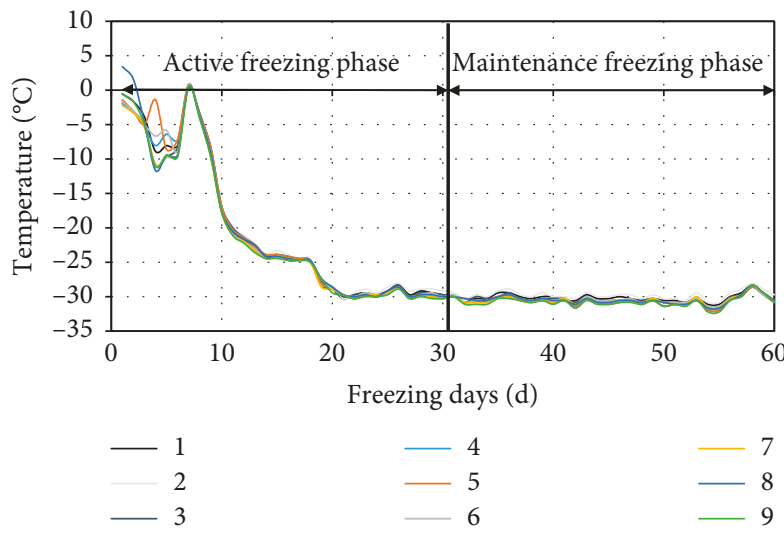

(a)

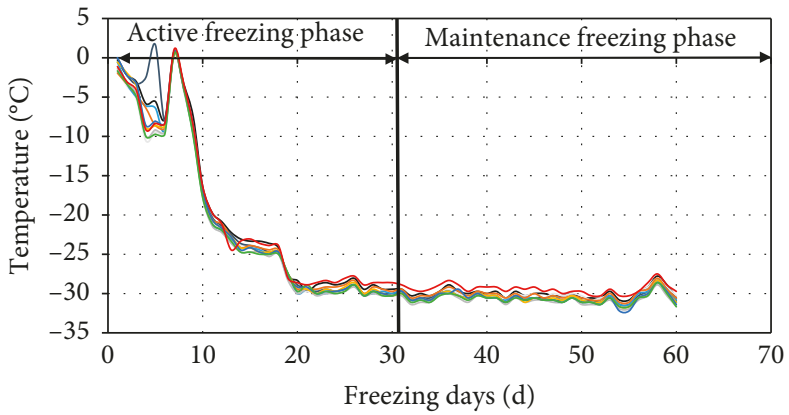

14

$-17$

$-10$

$-15$

$-18$

$-12$

$-13$

(b)

Figure 7: Curves of the temperature change in 19 branch pipes of the saline loop. (a) Branch nos. 1-9; (b) Branch nos. 10-19.

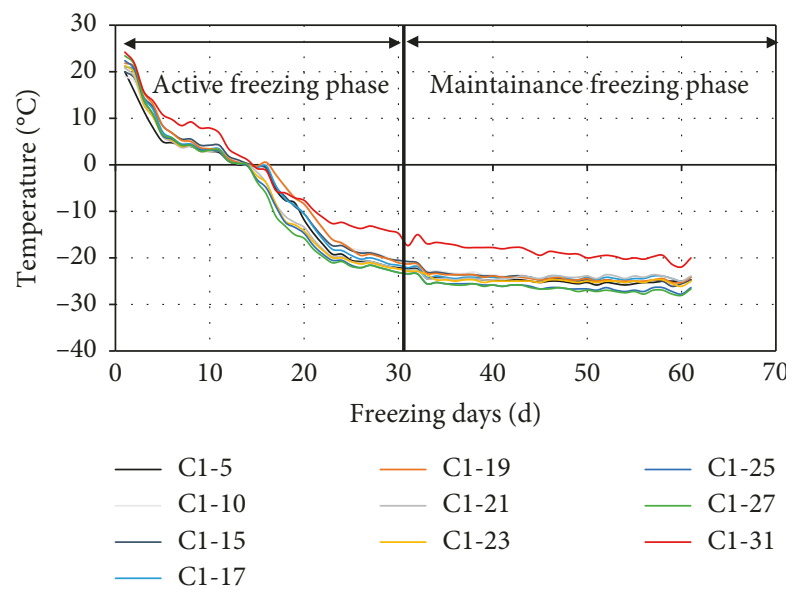

Figure 8: Curves of temperature and times at $\mathrm{C} 1$ temperature measuring hole.

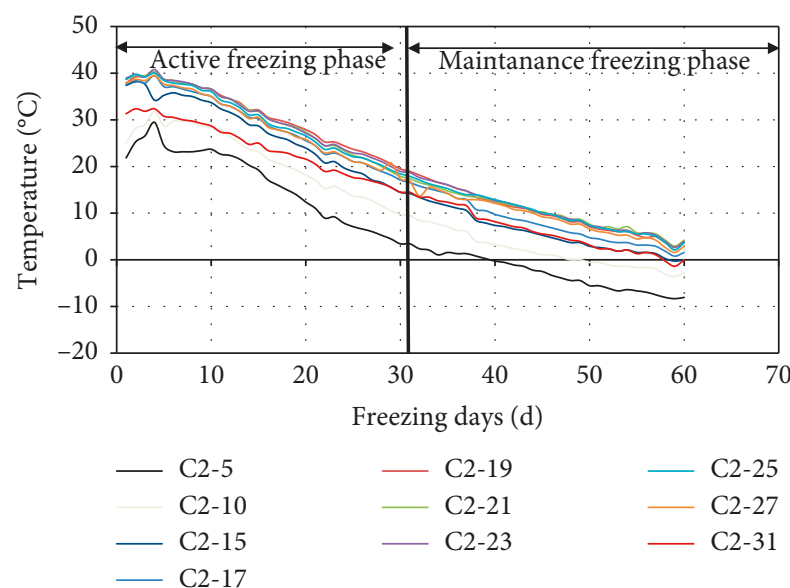

Figure 9: Curves of temperature and times at $\mathrm{C} 2$ temperature measuring hole.

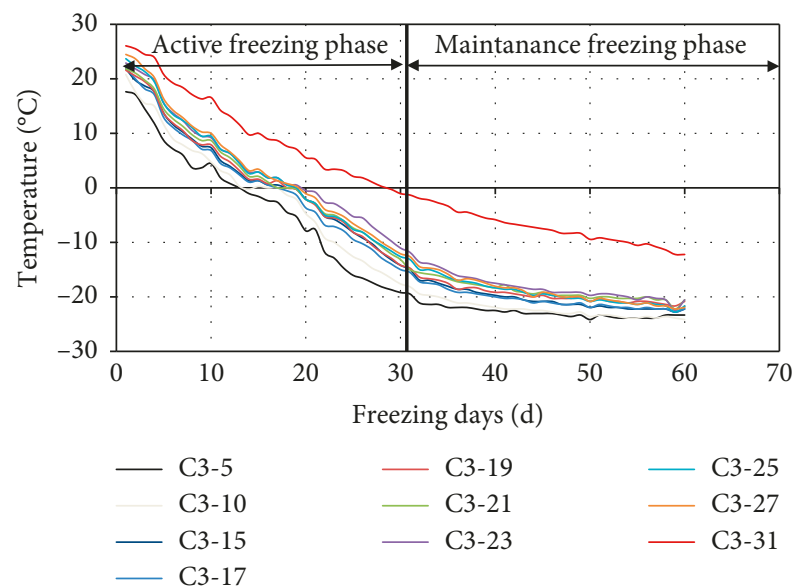

Figure 10: Curves of temperature and times at C3 temperature measuring hole.

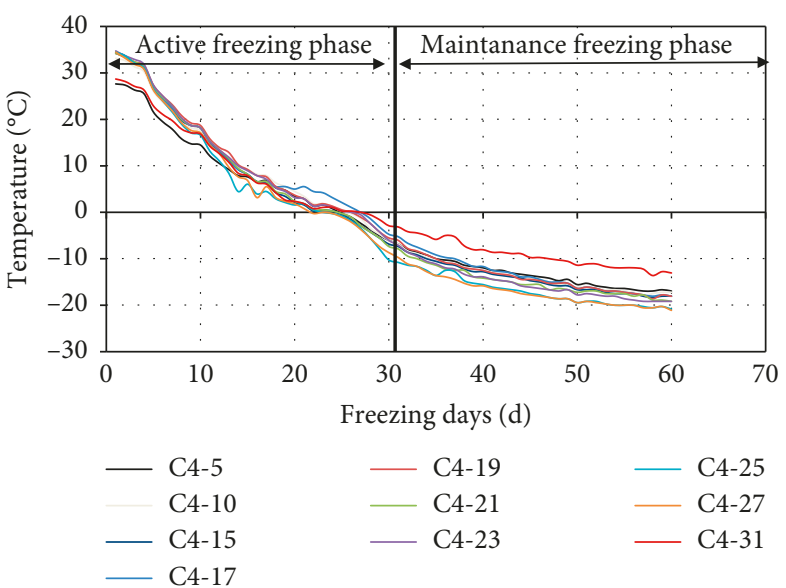

Figure 11: Curves of temperature and times at C4 temperature measuring hole. 


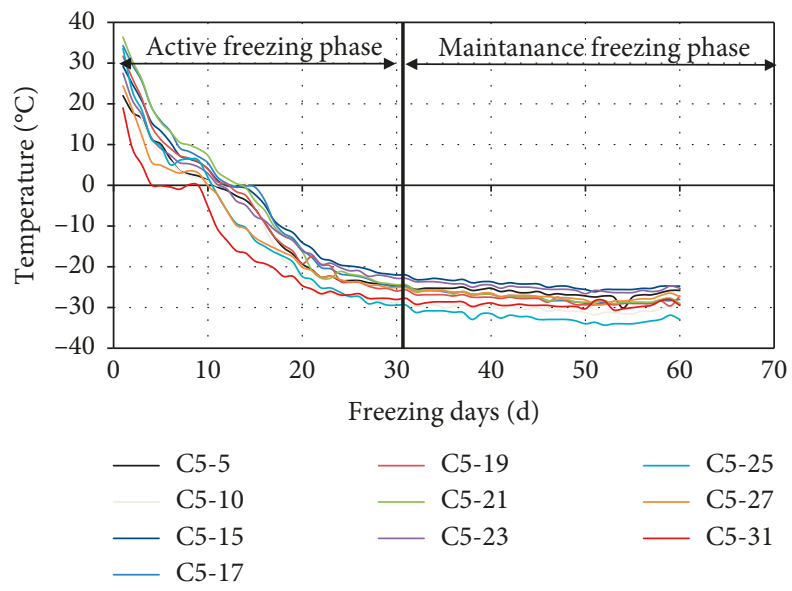

Figure 12: Curves of temperature and times at C5 temperature measuring hole.

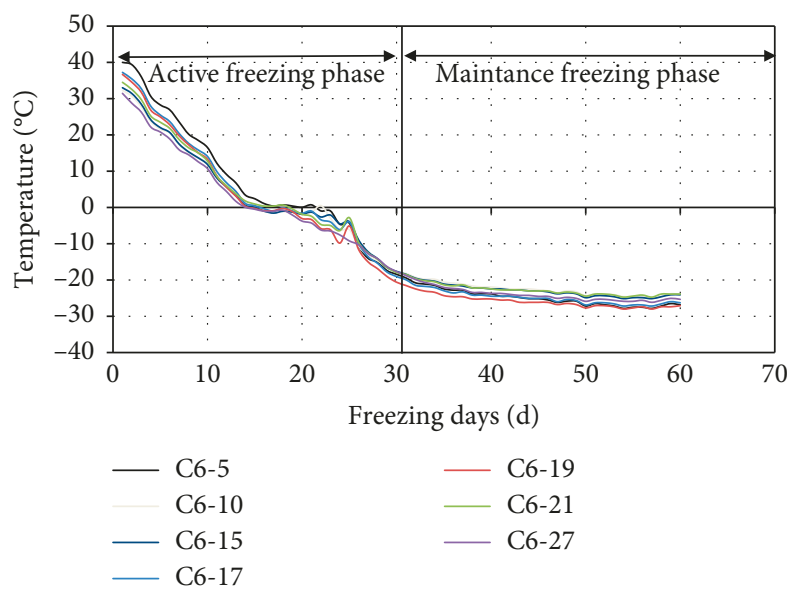

Figure 13: Curves of temperature and times at C6 temperature measuring hole.
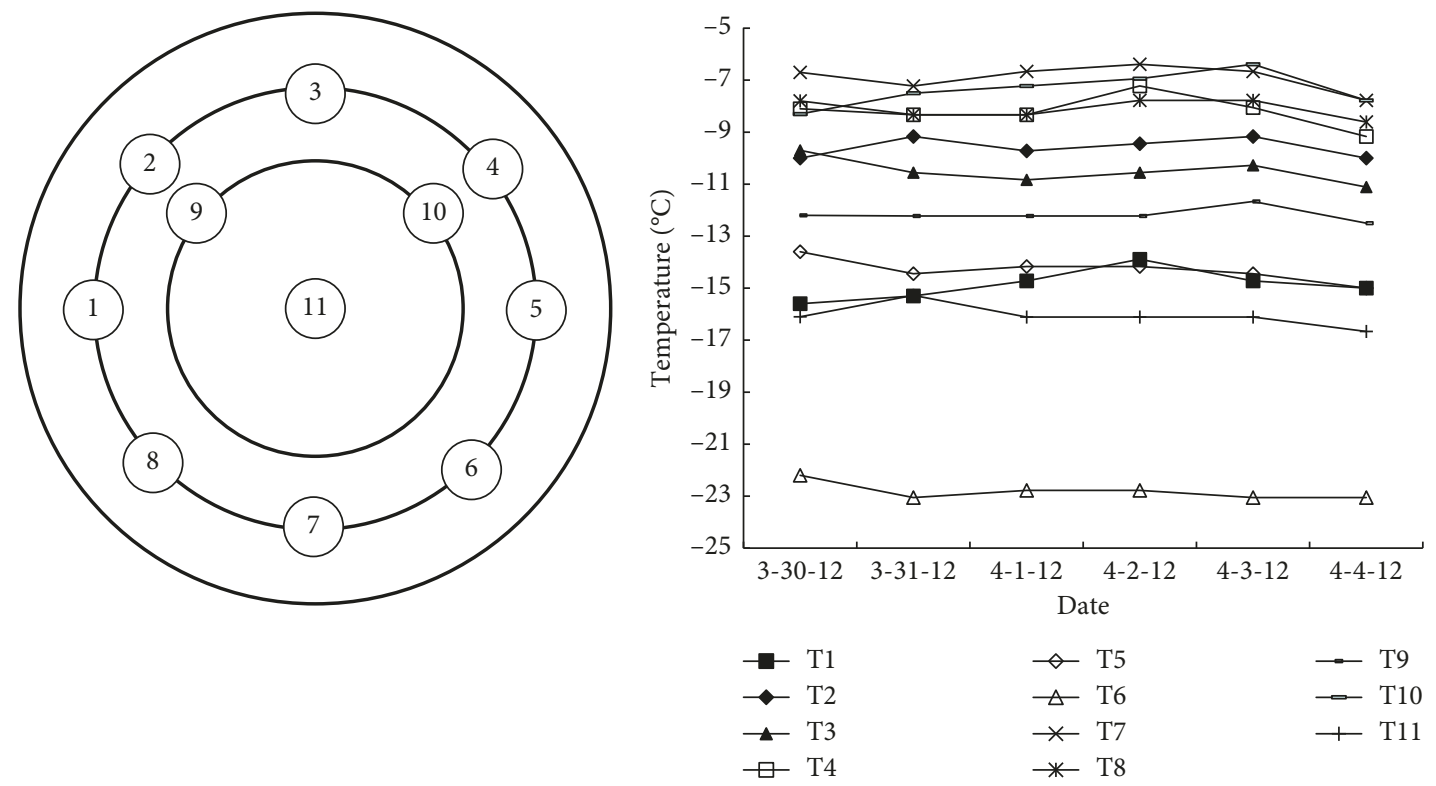

(a)

(b)

FIGURE 14: (a) Layout of measuring holes; (b) temperature of each measuring hole over time. 


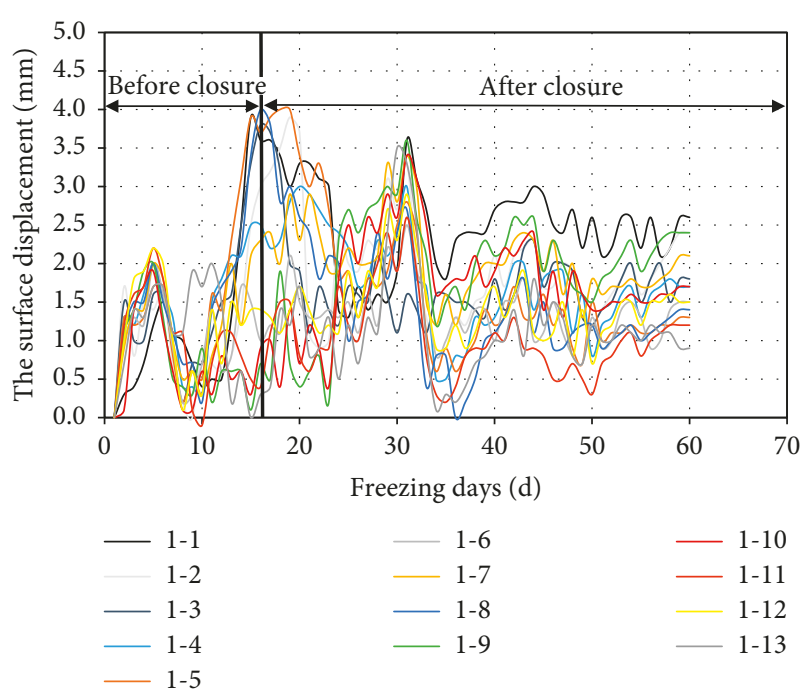

FIGURE 15: Curve for ground displacement change at DB1 section.

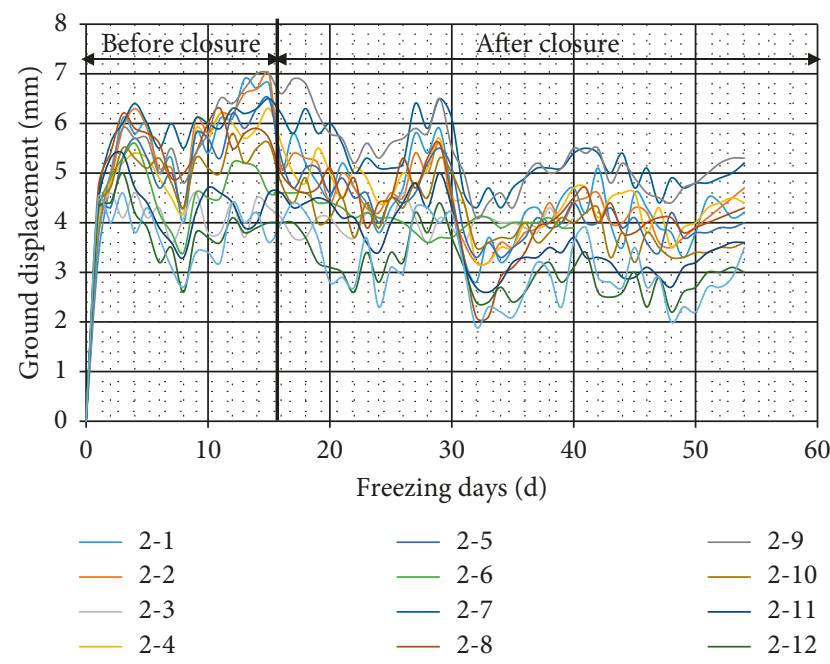

FIGURE 16: Ground displacement increment at DB2 section (positive values indicate ground expansion).

finally formed, the surface frost heave in the freezing area also reached the maximum value. In contrast, the maximum surface frost heave of a similar project is in the scale of $100 \mathrm{~mm}$ (derived from [30]). It can be seen that, in this project, the frost heave was greatly restrained due to the improvement of cement/soil piles. Therefore, in the future, when important assets such as buildings and pipelines are to be constructed, this method can be used to suppress frost heave.

4.6. Engineering Application. The shield launching location of the Nanjing Metro Line 10 was frozen from 18:00 on February 15, 2012, to April 15, 2012, for a total of 60 days. From April 5, 2012, removal of the tunnel door commenced. After removal of the tunnel door, a super-large shield machine with a total length of 120 meters, a total weight of 2,340 tons, and a diameter of 11.64 meters was assembled and successfully began to tunnel at 10 am on April 21, 2012. During the excavation process, there was no water or sand ingress, which ensured the safe launching of the largediameter shield under the protection of the frozen soil curtain. The measured value of the frozen ground provides guidance on the timing of shield departure. The project report recorded that ground instability and water permeation did not occur at the tunnel face during the subsequent excavation.

\section{Conclusions}

This paper reports details of the tunneling machine shield launching activities on the Nanjing Metro Line 10 crossriver tunnel project to introduce the frozen ground improvement method and to describe the process used during the project. On-site measurement research pertaining to the vertical freeze ground stabilization technology deployed during construction also is reported.

The surface settlement and seepage were successfully controlled by the combined cement treatment and ground freezing. On the other hand, the combination of cement treatment and ground freezing helps to control the freezinginduced heaving. The hydration heat in improved ground leads to an increase in ground temperature, and this leads to additional freezing duration.

\section{Data Availability}

The data used to support the findings of this study are available from the first author upon request.

\section{Conflicts of Interest}

The authors declare that they have no conflicts of interest.

\section{Acknowledgments}

This research was supported by the Hainan Provincial Natural Science Foundation of China (519QN333, 518QN307, and 518MS122) and the China Postdoctoral Science Foundation (2018M630722). The assistance by Jia Lin and Wang Zhixin from Hainan Investigation Institute of Hydrogeology and Engineering Geology is greatly appreciated.

\section{References}

[1] J. Morey and D. W. Campo, "Quality control of jet grouting on the Cairo metro," Proceedings of the Institution of Civil Engineers-Ground Improvement, vol. 3, no. 2, pp. 67-75, 1999.

[2] J. Hu, H. Zeng, and X. B. Wang, "Study on construction risk analysis and risk counter-measures of river-crossing tunnel of large-diameter metro," Applied Mechanics and Materials, vol. 166-169, no. 5, pp. 2680-2683, 2012.

[3] T. Asakura and Y. Kojima, "Tunnel maintenance in Japan," Tunnelling and Underground Space Technology, vol. 18, no. 23, pp. 161-169, 2003.

[4] J. Han, "Starting up construction technology with shield machine in the yellow river crossing tunnel," Water Resources 
and Hydropower Construction, vol. 2, pp. 38-40, 2008, in Chinese.

[5] G. Russo, A. Corbo, F. Cavuoto, and S. Autuori, "Artificial Ground Freezing to excavate a tunnel in sandy soil. Measurements and back analysis," Tunnelling and Underground Space Technology, vol. 50, pp. 226-238, 2015.

[6] Y. Sheng, "Freezing improvement for shield launching crossing-River tunnel in Shanghai," Modern Transportation Technology, vol. 5, no. 2, pp. 56-59, 2008, in Chinese.

[7] L. Wang and W. Wang, "Application of local soil freezing method in the launch of large diameter shield," Underground Engineering and Tunnels, vol. 1, pp. 39-41, 2006, in Chinese.

[8] J.-y. Yang, "Freezing technology for the launching of a superlarge diameter Slurry shield," Modern Tunneling Technology, vol. 47, no. 3, pp. 60-66, 2010, in Chinese.

[9] J. Yang, "Case study on arriving construction technology of Slurry shield machine with super-large diameter," Tunnel Construction, vol. 29, no. 5, pp. 548-551, 2009, in Chinese.

[10] P. Yang, J. M. Ke, J. G. Wang, Y. K. Chow, and F. B. Zhu, "Numerical simulation of frost heave with coupled water freezing, temperature and stress fields in tunnel excavation," Computers and Geotechnics, vol. 33, no. 6-7, pp. 330-340, 2006.

[11] P. Yu, "Starting up construction technology with shield machine in the yellow river crossing tunnel of the middle route project of South-to-north water diversion," South-toNorth Water Transfers and Water Science \& Technology, vol. 6, no. 4, pp. 54-57, 2008, in Chinese.

[12] J. F. Hao and M. X. Li, "Freezing technology application in the beginning of TBM for the project of yellow river crossing tunnel in the South-to-north water diversion middle route," South-to-North Water Transfers and Water Science \& Technology, vol. 6, no. 6, pp. 13-15, 2008, in Chinese.

[13] J. U. Hu and P. Yang, "Numerical analysis of temperature field within large-diameter cup-shaped frozen soil wall," Rock and Soil Mechanics, vol. 36, no. 2, pp. 523-531, 2015, in Chinese.

[14] J. Hu, Y. Liu, H. Wei, K. Yao, and W. Wang, "Finite-element analysis of heat transfer of horizontal ground-freezing method in shield-driven tunneling," International Journal of Geomechanics, vol. 17, no. 10, article 04017080, 2017.

[15] J. Hu, Y. Liu, Y. Li, and K. Yao, "Artificial ground freezing in tunnelling through aquifer soil layers: a case study in Nanjing Metro Line 2," KSCE Journal of Civil Engineering, vol. 22, no. 10, pp. 4136-4142, 2018.

[16] J. N. Shirlaw, J. C. W. Ong, H. B. Rosser, C. G. Tan, N. H. Osborne, and P. E. Heslop, "Local settlements and sinkholes due to EPB tunnelling," Geotechnical Engineering, vol. 156, no. 4, pp. 193-211, 2003.

[17] Á. Tóth, Q. Gong, and J. Zhao, "Case studies of TBM tunneling performance in rock-soil interface mixed ground," Tunnelling and Underground Space Technology, vol. 38, pp. 140-150, 2013.

[18] J. Zhao, Q. M. Gong, and Z. Eisensten, “Tunnelling through a frequently changing and mixed ground: a case history in Singapore," Tunnelling and Underground Space Technology, vol. 22, no. 4, pp. 388-400, 2007.

[19] S. H. Chew, A. H. M. Kamruzzaman, and F. H. Lee, "Physicochemical and engineering behavior of cement treated clays," Journal of Geotechnical and Geoenvironmental Engineering, vol. 130, no. 7, pp. 696-706, 2004.

[20] T. Namikawa and J. Koseki, "Effects of spatial correlation on the compression behaviour of a cement-treated column," Journal of Geotechnical and Geoenvironmental Engineering, vol. 139, no. 8, pp. 1346-1359, 2013.
[21] Y. Liu, E. J. Chen, S.-T. Quek, J.-T. Yi, and F.-H. Lee, "Effect of spatial variation of strength and modulus on the lateral compression response of cement-admixed clay slab," Géotechnique, vol. 65, no. 10, pp. 851-865, 2015.

[22] Y. Pan, G. Shi, Y. Liu, and F.-H. Lee, "Effect of spatial variability on performance of cement-treated soil slab during deep excavation," Construction and Building Materials, vol. 188, pp. 505-519, 2018.

[23] Y. Pan, Y. Liu, H. Xiao, F. H. Lee, and K. K. Phoon, "Effect of spatial variability on short- and long-term behaviour of axially-loaded cement-admixed marine clay column," Computers and Geotechnics, vol. 94, pp. 150-168, 2018.

[24] Y. Pan, Y. Liu, F. H. Lee, and K. K. Phoon, "Analysis of cement-treated soil slab for deep excavation support-a rational approach," Géotechnique, pp. 1-18, 2018.

[25] Y. Wu, X. Zhou, Y. Gao, L. Zhang, and J. Yang, "Effect of soil variability on bearing capacity accounting for non-stationary characteristics of undrained shear strength," Computers and Geotechnics, vol. 110, pp. 199-210, 2019.

[26] Y. Liu, Y. Pan, M. Sun, J. Hu, and K. Yao, "Lateral compression response of overlapping jet-grout columns with geometric imperfections in radius and position," Canadian Geotechnical Journal, vol. 55, no. 9, pp. 1282-1294, 2018.

[27] Y. Liu, J. Hu, H. Xiao, and E. J. Chen, "Effects of material and drilling uncertainties on artificial ground freezing of cementadmixed soils," Canadian Geotechnical Journal, vol. 54, no. 12, pp. 1659-1671, 2017.

[28] Y. Pan, Y. Liu, J. Hu, M. Sun, and W. Wang, "Probabilistic investigations on the watertightness of jet-grouted ground considering geometric imperfections in diameter and position," Canadian Geotechnical Journal, vol. 54, no. 10, pp. 1447-1459, 2017.

[29] Y. Pan, Y. Liu, and E. J. Chen, "Probabilistic investigation on defective jet-grouted cut-off wall with random geometric imperfections," Géotechnique, vol. 69, no. 5, pp. 420-433, 2019.

[30] L. Han, G. L. Ye, Y. H. Li, X. H. Xia, and J. H. Wang, "In situ monitoring of frost heave pressure during cross passage construction using ground-freezing method," Canadian Geotechnical Journal, vol. 53, no. 3, pp. 530-539, 2015. 


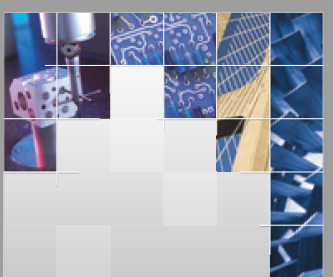

\section{Enfincering}
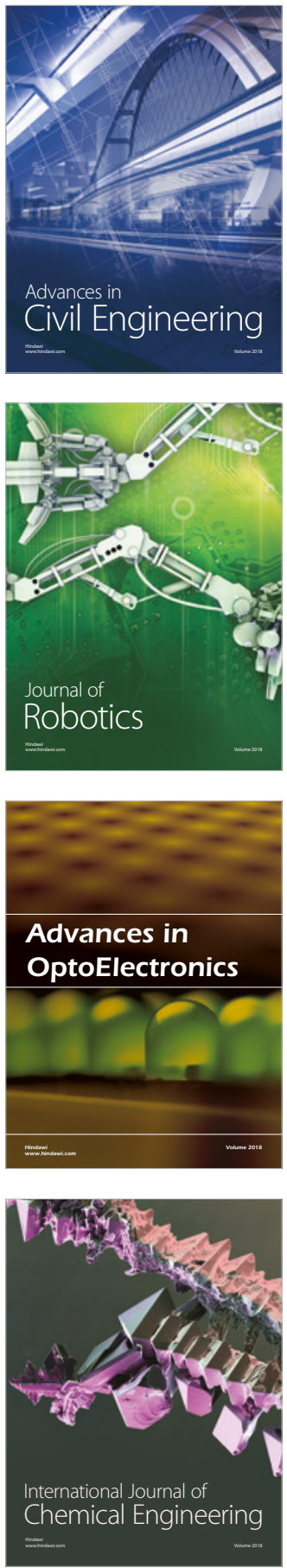

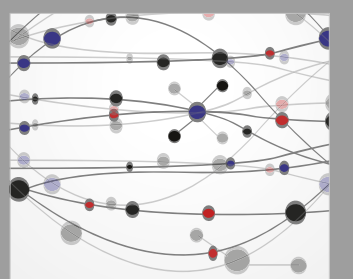

\section{Rotating \\ Machinery}

The Scientific World Journal

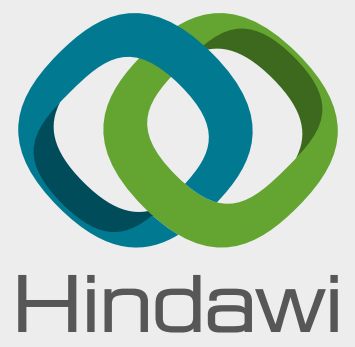

Submit your manuscripts at

www.hindawi.com
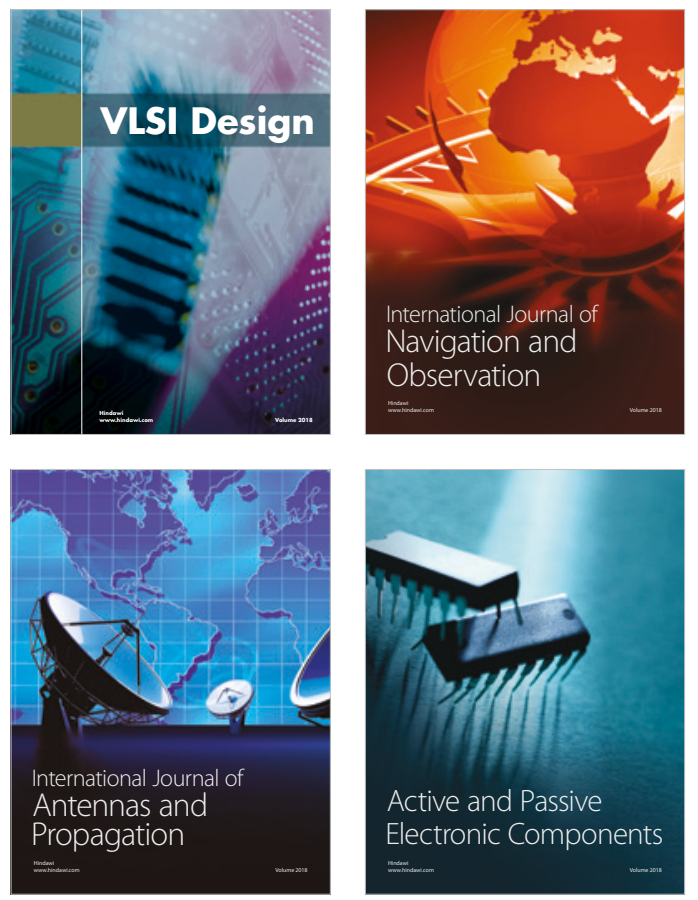
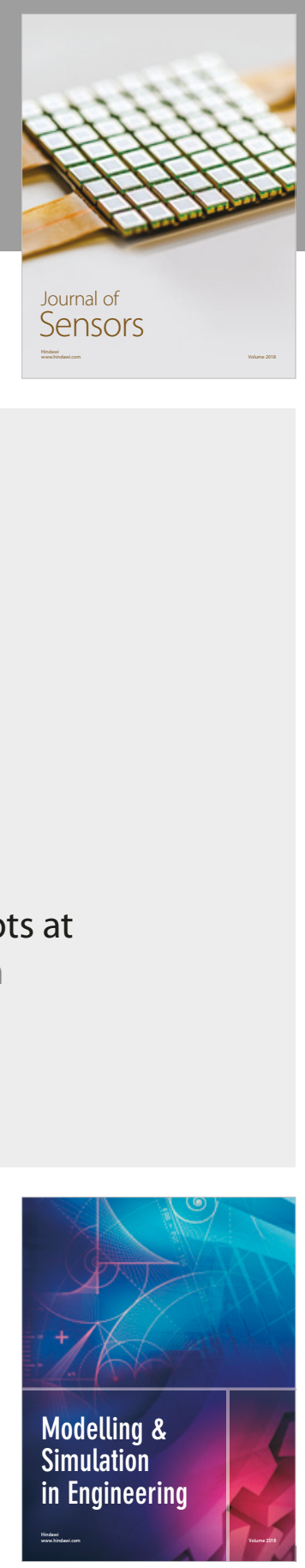

\section{Advances \\ Multimedia}
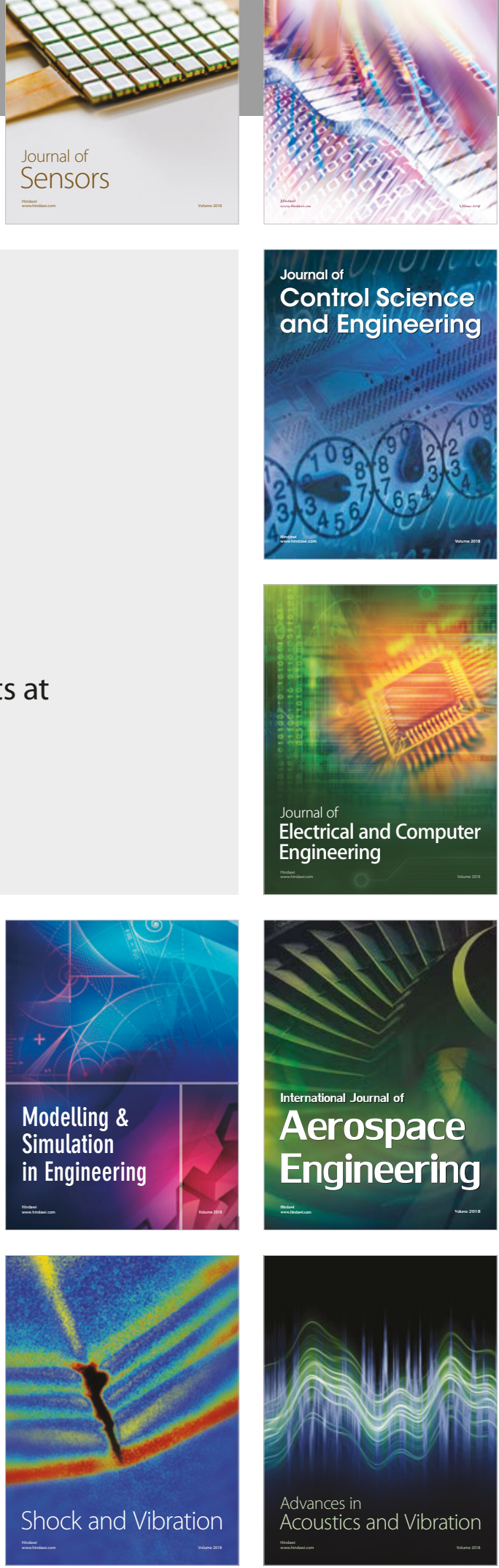